\title{
Reply: Vitamin D in Oncology
}

\author{
William B. Grant \\ Sunlight, Nutrition, and Health Research Center (SUNARC), San Francisco, CA, USA
}

The recent article 'Vitamin D in Oncology' [1] reviewed the evidence that vitamin $\mathrm{D}$ reduced the risk of cancer and increased rates of survival after diagnosis. The article acknowledged strong support for the ultraviolet-B-(UVB)-vitamin D-cancer hypothesis from ecological, laboratory, and observational studies. But the evidence was deemed inconclusive for several reasons:

i) Possible confounding by other cancer risk-modifying factors with the vitamin $\mathrm{D}$ index

ii) Some observational studies found direct correlations between prediagnostic serum 25-hydroxyvitamin D (25(OH)D) levels and cancer incidence rates

iii) A general lack of randomized controlled trials (RCTs) with vitamin $\mathrm{D}$ and cancer outcomes.

This letter addresses these 3 concerns.

The concern about confounding factors was raised in [2]. The factors stated were obesity, solar exposure, and skin legitimate modifiers of serum $25(\mathrm{OH}) \mathrm{D}$ that should not be considered confounding factors. In fact, 1 study of cancer incidence used solar exposure and skin pigmentation to develop a vitamin D index [3]. However, an analysis from the Women's Health Initiative (WHI) study found that the predictive model for $25(\mathrm{OH}) \mathrm{D}$ explained $21 \%$ of the variation in $25(\mathrm{OH}) \mathrm{D}$ concentrations [4]. Another study found large variations of serum $25(\mathrm{OH}) \mathrm{D}$ level for any oral vitamin D intake [5]. Thus, because serum 25(OH)D levels cannot be predicted based on known factors, it seems unlikely that confounding factors would affect the serum $25(\mathrm{OH}) \mathrm{D}$ levels in cancer studies systematically rather than randomly. As for the reverse causality also mentioned, people generally do not know that they have cancer until it is diagnosed; so having cancer before diagnosis is unlikely to affect serum $25(\mathrm{OH}) \mathrm{D}$ levels.

Most recent ecological studies of the UVB vitamin D cancer hypothesis include many cancer risk-modifying factors in the analysis [6]. Some ecological studies also used non-melanoma skin cancer incidence or mortality rates as the index of solar UVB irradiance [7]. Solar UVB irradiance is the strongest risk factor for non-melanoma skin cancer deaths. Other than vitamin D production, researchers have proposed no credible mechanism to explain the findings of ecological studies of solar UVB and cancer rates in Australia, China, France, Japan, Russia, Spain, and the USA.

As to direct correlations between serum 25(OH)D and cancer incidence rates, a systematic problem appears with prospective studies of cancer outcome with respect to serum 25(OH)D levels determined at time of enrollment: as followup time increases, the prognostic value of the single serum $25(\mathrm{OH}) \mathrm{D}$ level decreases. This effect is most apparent for breast cancer. Breast cancer has 2 peaks in detection, spring and fall [8]. The explanation is that melatonin levels are higher in winter, when daylight hours are shorter, and vitamin $\mathrm{D}$ levels are higher in summer. A review of breast cancer risk with respect to follow-up time found that case control studies with no follow-up time found strong inverse correlations with respect to serum $25(\mathrm{OH}) \mathrm{D}$, but as follow-up time increased in nested case control studies, the risk ratio tended toward unity [9]. Another study found inverse correlations between serum 25( $\mathrm{OH}) \mathrm{D}$ level and breast cancer incidence for follow-up times up to 10 years, but it found a direct correlation for follow-up times between 15 and 20 years [10]. For nonHodgkin's lymphoma, an inverse correlation of incidence with respect to serum $25(\mathrm{OH}) \mathrm{D}$ level was found for follow-up times up to 7 years, with a direct correlation for longer followup times [11]. The observational studies mentioned in [1] reporting no correlation or a direct correlation between serum $25(\mathrm{OH}) \mathrm{D}$ level and cancer incidence rates had follow-up times between 6 and 17 years.

One RCT used a high enough level of vitamin D3 (1,100 IU/day) to be effective [12]. It found a $77 \%$ reduction (relative risk $=0.23 ; \mathrm{CI}: 0.09,0.60 ; \mathrm{p}<0.005$ ) in all-cancer incidence between the ends of the 1 st and 4 th years for vitamin D plus calcium. In the calcium arm, the trial found a $41 \%$ non-significant reduction (relative risk $=0.59$; CI: 0.29 , $1.21 ; \mathrm{p}=0.15)$.

\section{KARGER}

Fax +497614520714

Information@Karger.de

www.karger.com (c) 2011 S. Karger GmbH, Freiburg

$1661-4119 / 11 / 0186-0355 \$ 38.00 / 0$

Accessible online at:

www.karger.com/fok
William B. Grant, Ph.D.

Sunlight, Nutrition, and Health Research Center (SUNARC)

P.O. Box 641603, San Francisco, CA 94164-1603, USA

wbgrant@infionline.net 
A recent analysis of a subset of those in the WHI found that women not taking calcium or vitamin D supplements at the start had a $14-20 \%$ reduction of breast cancer and a $17 \%$ non-significant reduction of colorectal cancer, whereas those taking either supplement at the start had no significant change in cancer incidence rates [13]. This finding is consistent with the fact that the relationship between serum 25(OH)D level and cancer incidence rates changes rapidly at lower serum $25(\mathrm{OH}) \mathrm{D}$ levels and then more slowly at levels higher than $100 \mathrm{nmol} / \mathrm{l}$ or so [14].

Thus, the concerns raised in [1] have explanations that counter the doubts regarding the UVB vitamin D cancer hypothesis. Increasing serum 25(OH)D levels to $110 \mathrm{nmol} / \mathrm{l}$ globally would reduce cancer rates by an estimated $20-25 \%$ and increase life expectancy by 2 years [15]. Because vitamin D supplementation up to $4,000 \mathrm{IU} /$ day is associated with limited risks [16], waiting another 5 years or so for 'definitive' RCTs to demonstrate efficacy and lack of harm does not make sense. Although RCTs are required for pharmaceutical drugs, they should not be required for vitamin $\mathrm{D}$ for cancer prevention: solar UVB is the primary source of vitamin $\mathrm{D}$, and abundant evidence from ecological and observational studies indicates i) that higher UVB doses and serum 25(OH)D levels are associated with reduced risk and increased survival and ii) that causality of vitamin D for cancer risk reduction is largely established [17]. In addition, conducting RCTs without measuring serum $25(\mathrm{OH}) \mathrm{D}$ level at time of enrollment and every year or 2 of the study will reduce the ability of the study to determine the effect of vitamin $\mathrm{D}$ because cancer risk is related to serum $25(\mathrm{OH}) \mathrm{D}$ levels, not oral vitamin $\mathrm{D}$ intake per se [13].

\section{Disclosure Statement}

I receive funding from the UV Foundation (McLean, VA), the Sunlight Research Forum (Veldhoven), Bio-Tech-Pharmacal (Fayetteville, AR), the Vitamin D Council (San Luis Obispo, CA), and the Vitamin D Society (Canada).

\section{References}

1 Arends J: Vitamin D in oncology. Forsch Komplementmed 2011;18:176-184.

2 Manson JE, Mayne ST, Clinton SK: Vitamin D and prevention of cancer - ready for prime time? $\mathrm{N}$ Engl J Med 2011;364:1385-1387.

3 Giovannucci E, Liu Y, Rimm EB, Hollis BW, Fuchs CS, Stampfer MJ, Willett WH: Prospective study of predictors of vitamin D status and cancer incidence and mortality in men. J Natl Cancer Inst 2006;98:451-459.

4 Millen AE, Wactawski-Wende J, Pettinger M, Melamed ML, Tylavsky FA, Liu S, Robbins J, LaCroix AZ, LeBoff MS, Jackson RD: Predictors of serum 25-hydroxyvitamin D concentrations among postmenopausal women: the Women's Health Initiative Calcium plus Vitamin D clinical trial. Am J Clin Nutr 2010;91:1324-1335.

5 Garland CF, French CB, Baggerly LL, Heaney RP: Vitamin D supplement doses and serum 25-hydroxyvitamin D in the range associated with cancer prevention. Anticancer Res 2011:31:617-622.

6 Grant WB, Mohr SB: Ecological studies of ultraviolet $\mathrm{B}$, vitamin $\mathrm{D}$ and cancer since 2000. Ann Epidemiol 2009;19:446-454.
Grant WB: An ecologic study of cancer mortality rates in Spain with respect to indices of solar UV irradiance and smoking. Int J Cancer 2007;120: 1123-1127.

8 Oh EY, Ansell C, Nawaz H, Yang CH, Wood PA, Hrushesky WJ: Global breast cancer seasonality.

Breast Cancer Res Treat 2010;123:233-243.

9 Grant WB: Effect of interval between serum draw and follow-up period on relative risk of cancer incidence with respect to 25-hydroxyvitamin D level. Implications for meta-analyses and setting vitamin D guidelines. Dermatol Endocrinol 2011;3:199-204.

10 Robien K, Cutler GJ, Lazovich D: Vitamin D intake and breast cancer risk in postmenopausal women: the Iowa Women's Health study. Cancer Causes Control 2007;18:775-782.

11 Lim U, Freedman DM, Hollis BW, Horst RL, Purdue MP, Chatterjee N, Weinstein SJ, Morton LM, Schatzkin A, Virtamo J, Linet MS, Hartge P, Albanes D: A prospective investigation of serum 25-hydroxyvitamin D and risk of lymphoid cancers. Int J Cancer 2009;124:979-986.

12 Lappe JM, Travers-Gustafson D, Davies KM, Recker RR, Heaney RP: Vitamin D and calcium supplementation reduces cancer risk: results of a randomized trial. Am J Clin Nutr 2007;85:1586-1591.
13 Bolland MJ, Grey A, Gamble GD, Reid IR: Calcium and vitamin D supplements and health outcomes: a reanalysis of the Women's Health Initiative (WHI) limited-access data set. Am J Clin Nutr 2011;94:1144 1149.

14 Grant WB: Relation between prediagnostic serum 25-hydroxyvitamin D level and incidence of breast, colorectal, and other cancers. J Photochem Photobiol B 2010;101:130-136.

15 Grant WB: An estimate of the global reduction in mortality rates through doubling vitamin D levels. Eur J Clin Nutr 2011;65:1016-1026.

16 Ross AC, Manson JE, Abrams SA, Aloia JF, Brannon PM, Clinton SK, Durazo-Arvizu RA, Gallagher JC, Gallo RL, Jones G, Kovacs CS, Mayne ST, Rosen CJ, Shapses SA: The 2011 report on dietary reference intakes for calcium and vitamin D from the Institute of Medicine: what clinicians need to know. J Clin Endocrinol Metab 2011; 96:53-58.

17 Grant WB: How strong is the evidence that solar ultraviolet $\mathrm{B}$ and vitamin $\mathrm{D}$ reduce the risk of cancer? An examination using Hill's criteria for causality. Dermatoendocrinology 2009;1:17-24. 